\title{
Cholesterol Transport and Regulation in the Mammary Gland
}

\author{
Edgar C. Ontsouka $\cdot$ Christiane Albrecht
}

Received: 10 September 2013 / Accepted: 22 January 2014 / Published online: 9 February 2014

(C) Springer Science+Business Media New York 2014

\begin{abstract}
The milk-producing alveolar epithelial cells secrete milk that remains after birth the principal source of nutrients for neonates. Milk secretion and composition are highly regulated processes via integrated actions of hormones and local factors which involve specific receptors and downstream signal transduction pathways. Overall milk composition is similar among mammalian species, although the content of individual constituents such as lipids may significantly differ from one species to another. The milk lipid fraction is essentially composed of triglycerides, which represent more than $95 \%$ of the total lipids in human and commercialized bovine milk. Though sterols, including cholesterol, which is the major milk sterol, represent less than $0.5 \%$ of the total milk lipid fraction, they are of key importance for several biological processes. Cholesterol is required for the formation of biological membranes especially in rapidly growing organisms, and for the synthesis of sterol-based compounds. Cholesterol found in milk originates predominantly from blood uptake and, to a certain extent, from local synthesis in the mammary tissue. The present review summarizes current knowledge on cellular mechanisms and regulatory processes determining intra- and transcellular cholesterol transport in the mammary gland. Cholesterol exchanges between the blood, the mammary alveolar cells and the milk, and the likely role of active cholesterol transporters in these processes are discussed. In this context, the hormonal regulation and signal transduction pathways promoting active cholesterol transport as well as potential regulatory crosstalks are highlighted.
\end{abstract}

E. C. Ontsouka $\cdot$ C. Albrecht $(\bowtie)$

Institute of Biochemistry and Molecular Medicine, Faculty of

Medicine, University of Bern, Buehlstrasse 28, 3012 Bern,

Switzerland

e-mail: christiane.albrecht@ibmm.unibe.ch

E. C. Ontsouka $\cdot$ C. Albrecht

Swiss National Center of Competence in Research, NCCR

TransCure, University of Bern, Bern, Switzerland
Keywords ABC transporters $\cdot$ Cholesterolemia $\cdot$ Cholesterol transport · Hormonal regulation · Lipid secretion · Mammary gland $\cdot$ Milk lipid composition $\cdot$ Signaling pathways

$\begin{array}{ll}\begin{array}{l}\text { Abbreviations } \\ \text { ABC transporter }\end{array} & \text { ATP-binding cassette transporter } \\ \text { ACAT } & \begin{array}{l}\text { Acyl-coenzyme A: cholesterol } \\ \text { acyltransferase }\end{array} \\ \text { ApoA-I } & \text { Apolipoprotein A-I } \\ \text { CEH } & \text { Cholesteryl ester hydrolase } \\ \text { CLD } & \text { Cytoplasmic lipid droplets } \\ \text { HDL } & \text { High density lipoprotein } \\ \text { HMG-CoA } & \text { 3-hydroxy-3-methylglutaryl-CoA } \\ \text { HSL } & \text { Hormone-sensitive lipase } \\ \text { JAK-2 } & \text { Janus-kinase-2 } \\ \text { LAL } & \text { Lysosomal acid lipase } \\ \text { LDL } & \text { Low density lipoprotein } \\ \text { LPL } & \text { Lipoprotein lipase } \\ \text { LXR } & \text { Liver X receptor } \\ \text { MAPK } & \text { Mitogen-activated protein kinase } \\ \text { MEC } & \text { Alveolar mammary epithelial cell } \\ \text { MFG } & \text { Milk fat globule } \\ \text { NPC } & \text { Niemann-Pick type C } \\ \text { OSBP } & \text { Oxysterol-binding protein } \\ \text { ORP } & \text { OSBP-releated protein } \\ \text { PPAR } & \text { Peroxisome proliferator-activated receptor } \\ \text { PREB } & \text { Prolactin regulatory element binding } \\ \text { SR-BI } & \text { Scavenger receptor class B type I } \\ \text { SREBP } & \text { Sterol response element binding protein } \\ \text { VLDL } & \\ & \text { Very low density lipoprotein } \\ \text { OSP } & \end{array}$

Introduction

Though cholesterol represents less than $0.5 \%$ of the total milk lipid fraction, it is of key importance for biological processes 
such as the formation of biological membranes and the synthesis of sterol-based compounds. Experiments performed in ruminants by using radioactive compound showed that approximately $20 \%$ of cholesterol in milk originates from de novo synthesis in the mammary tissues while the major fraction of cholesterol $(\sim 80 \%)$ is derived from the blood serum [1]. Cholesterol is released into milk by milk-producing alveolar mammary epithelial cells (MEC), which are in close proximity and interaction with other mammary cell types such as myoepithelial cells. Altogether, these cells constitute the epithelial barrier separating the blood from alveolar compartments. As depicted in Fig. 1, MEC are glandular polarized cells with functionally distinct basolateral and apical plasma membrane domains. It is established that milk constituents enter the milk compartment by various mechanisms, which belong to the paracellular and transcellular routes of transport [2,3]. The transport of cholesterol across the epithelial barrier may also involve active transport by membrane transporters such as ATP-binding cassette
(ABC) transporters [4]. The present review summarizes the mechanisms mediating the transcellular transport of cholesterol into the milk and describes the regulatory mechanisms involved.

\section{Health and Disease Aspects of Cholesterol}

Cholesterol is a neutral lipid, which is a structural constituent of biological membranes. It is accumulated in liquid-ordered, detergent-resistant membrane domains called lipid rafts, which are an important platform for signal transduction pathways mediating various cellular processes including cell growth, survival, and others [5, 6]. Moreover, cholesterol is a precursor molecule in the synthesis of multiple sterol-based compounds (e.g. steroid hormones, vitamin D). Cholesterol demand is elevated during the period of a rapid organ growth, development and maturation, such as during fetal and early postnatal life when a rapid growth of tissues and key systems

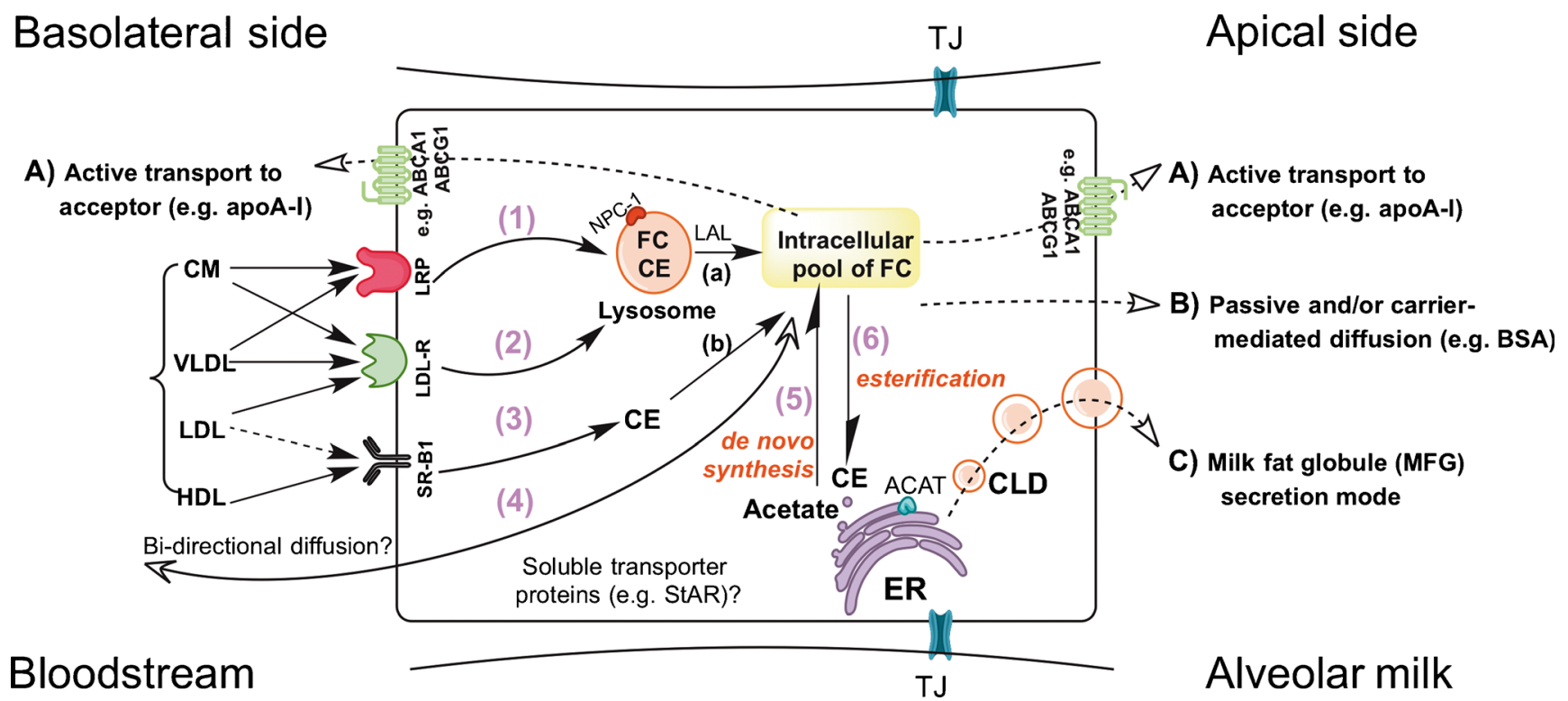

Fig. 1 Overview of potential cholesterol transport mechanisms in mammary alveolar epithelial cells (MEC). Similar to uptake mechanisms shown in other polarized cell types [141], MEC are supposed to take up cholesterol both as free cholesterol (FC) and cholesteryl esters (CE) from circulating chylomicrons (CM), very low density lipoprotein (VLDL), low-density lipoproteins (LDL) and high-density lipoprotein (HDL) via various mechanisms involving 1) LDL-related protein (LRP), 2) receptor mediated endocytosis of the LDL-receptor (LDL-R), and 3) receptormediated uptake by the scavenger receptor class B type I (SR-B1). Additional cholesterol uptake is likely to occur by diffusional processes (4) which may involve the action of cytosolic transport proteins such as the steroidogenic acute regulatory protein (StAR). Cholesterol taken up from the blood circulation in addition to cholesterol synthesized de novo in the endoplasmic reticulum (ER) via the 3-hydroxy-3-methylglutaryl-CoA (HMG-CoA)-reductase pathway (5) determine its intracellular pool. Depending on the cellular activities, FC can be esterified by acyl-coenzyme A: cholesterol acyltransferase (ACAT) expressed in the ER and stored as $\mathrm{CE}$ in lipid droplets (CLD) originating from the ER (6). It should be noted that CE taken up from lipoprotein particles (e.g. via LDL-R) is initially directed to endosomes where it is hydrolyzed by lysosomal acidic lipase (LAL) and exported by Niemann-Pick type C (NPC) protein as FC (a), whereas the $\mathrm{CE}$ taken up via SR-B1 are hydrolyzed to $\mathrm{FC}$ under the action of cytosolic CE neutral hydrolase (b). ATP-binding cassette (ABC) transporters such as $\mathrm{ABCA} 1$ and $\mathrm{ABCG} 1$ which are situated at the apical and basolateral plasma membrane mediate the transfer of cholesterol to extracellular acceptor proteins (e.g. lipid-poor apolipoprotein (apo)-A1; pathway A). Pathway A requires the hydrolysis of ATP which, in the case of ABCA1 induces conformational changes that allow apoA-1 binding and further cholesterol transfer and release. As the localization and transport activities of ABCG5 and ABCG8 in MEC have not been investigated so far, these transporters are not illustrated. Pathway B shows that cholesterol might cross the apical plasma membrane facing the alveolar lumen by diffusion and binding to extracellular acceptors such as BSA. The milk fat globule (MFG) secretion mode (pathway C) involves the migration of cytoplasmic lipid droplets (CLD) from the ER towards the apical membrane. At the apical plasma membrane domain, CLD are progressively surrounded by the plasma membrane and then pinched off into the milk. $T J$ tight junctions 
occurs [7]. Cholesterol ingested with milk or other dairy products is an important source of dietary cholesterol, which influences cholesterolemia in humans. In this context, it has been shown that the level of total circulating cholesterol in 6 months-aged babies fed with breast milk is similar to that in adults [8]. Moreover, cholesterolemia was elevated in babies fed with cholesterol-rich breast milk as compared to cholesterollow milk replacer [9]. Growing neonates were estimated to have exceedingly high cholesterol intake by milk consumption [10] which, however, seems to be not associated with elevated risks of developing cardiovascular disease or other diseases such as cancer later in life. In contrast, some studies have even suggested that elevated cholesterolemia following breastfeeding has beneficial health effects [11-13]. In this regard, it is thought that LDL cholesterol contributes to settle an efficient immune protection that lowers the mortality and morbidity in neonates $[14,15]$. This is explained by the fact that high levels of circulating LDL particles might play a role in facilitating the generation of antibodies. In analogy, it has been observed that the susceptibility to infections and allergic diseases was remarkably high in neonates having low LDLcholesterol as compared to those with elevated cholesterolemia $[15,16]$, implying a reduced ability of generating antibodies in newborns exhibiting lower blood LDLcholesterol levels. Although a consensus about the beneficial effects of cholesterol in childhood is still missing, there are also studies proposing that elevated cholesterol blood levels in neonates might have long-term health benefits, as it seems lowering the vulnerability to develop cardiovascular diseases in older age $[11,13]$. The high cholesterol content of colostrum (Table 1) may be important to meet the elevated demand in neonates. However, it can be assumed that, with developmental growth and increased endogenous cholesterol

Table 1 Constituents in human milk

\begin{tabular}{lll}
\hline Milk constituent & Colostrum & Mature milk \\
\hline Lactose (g/L) & $20-30$ & 67 \\
Oligosaccharides (g/L) & $22-24$ & $12-14$ \\
Total protein (g/L) & 16 & 9 \\
Total lipids (\%) & 2 & 3.5 \\
Triglycerides (\% total lipids) & $97-98$ & $97-98$ \\
Cholesterol (\% total lipids) & $0.7-1.3$ & $0.4-0.5$ \\
Cholesterol (mg/dL) & $>30$ & $10-20$ \\
Cholesteryl esters (mg/dL) & $\sim 5$ & $\sim 1$ \\
Phospholipids $(\%$ total lipids) & 1.1 & $0.6-0.8$ \\
Fatty acids (weight \%) & 88 & 88 \\
\hline
\end{tabular}

This table has been adapted from [109, 143] with permission from Elsevier. In the original references additional information for other milk constituents (e.g. vitamins and minerals) can be found

${ }^{a}$ Specifications of cholesterol ester contents are taken from reference [144]. Data are expressed as range or single values production by neonatal tissues [17], cholesterol provided through the intake of mature milk is sufficient to fulfill the tissue cholesterol demand. Cholesterol remains the major sterol in milk, where it is found in both unesterified and esterified forms. The latter represents approximately $10 \%$ of milk cholesterol [18]. However, the milk lipid content including cholesterol varies considerably between species (Table 2).

Unlike young organisms, chronically elevated cholesterolemia in adults is commonly associated with a variety of pathological conditions including cardiovascular disease [19]. It is therefore considered as a major characteristic of disturbed cellular cholesterol homeostasis. There are several reports indicating an association between high dietary cholesterol intake and increased incidence of breast cancers especially in developed countries where diets are lipid-enriched [20-22]. Elevated cholesterol levels were associated with inflammatory breast cancer, which is a particularly invasive and thereby lethal subset of breast cancer [23-25]. It has been demonstrated that mammary tissues from inflammatory and non-inflammatory breast cancer initially contain greater amounts of cholesterol stored as lipid droplets in comparison to healthy mammary cells [26]. More specifically, it was shown that non-inflammatory breast cancer cells are reliant on extracellular cholesterol supply to maintain intracellular stores, while the inflammatory breast cancer cells are capable of maintaining intracellular cholesterol concentration relatively independent of extracellular cholesterol levels. In the context of this study [26] the authors concluded that in the absence of cholesterol in their immediate cellular microenvironment tumor cells might drive tumor cell invasion. Surely, the importance of cholesterol regulation in cancer invasiveness requires further investigations. It is also important to note that findings regarding the relationship between the lipid profile and breast cancer are somehow conflicting. Since long, there are data supporting an association between breast cancer rates and fat intake [27-30]. Some case-control studies comparing the association between serum lipids and breast cancer reported breast cancer patients with high plasma triglycerides $[31,32]$ and, inversely, low cholesterol levels [31] as compared to controls. Those findings disagreed, at least partly, with reports that higher plasma triglycerides, cholesterol and phospholipids are found in patients with breast cancer [33].

Table 2 Total lipid and cholesterol levels in milk commonly consumed by humans

\begin{tabular}{lll}
\hline Milk origin & Total lipids $(\%)$ & cholesterol (mg per 100 g fat) \\
\hline Cow & $1.38-5.10$ & $239-300$ \\
Sheep & $5.79-6.45$ & 290 \\
Goat & $2.75-6.43$ & 340
\end{tabular}

Data are adapted from $[18,145,146]$ and are published with permission from Elsevier. Data shown are expressed as range or single values 


\section{Cholesterol Transport Into Milk}

Literature search on cholesterol transport in the mammary gland demonstrates that this research area is relatively scarcely investigated. Results from few previous studies significantly improved our basic understanding of how various substrates, including lipids, are transported across the epithelial barrier into the milk compartment [1-3, 34, 35]. Recent studies tempted to decipher the mechanisms of transcellular cholesterol exchanges between the blood circulation, MEC, and milk compartments, has led to the speculation about possible mechanisms [4]. In general, the transport mechanisms determining the transcellular passage of cholesterol into milk involve i) the uptake of circulating cholesterol from the body reservoir (i.e. blood circulation), where it circulates bound to carrier proteins such as very low-density lipoproteins (VLDL), low-density lipoproteins (LDL), high-density lipoproteins (HDL), and chylomicrons [18], ii) passage across the basolateral plasma membrane domains oriented towards the blood circulation, iii) intracellular trafficking and compartmentalization, and ultimately iiii) passage across the apical membrane facing the alveolar lumen where milk resides (Fig. 1).

Mechanisms of Cholesterol Uptake at the Basolateral Plasma Membrane

Figure 1 illustrates that cholesterol uptake in the mammary gland involves co-existing enzyme and/or carrier-mediated as well as receptor-mediated processes. In this context, it is not yet clear which mechanism is the predominant gateway for cholesterol uptake by MEC prior to its release into milk.

As depicted in Fig. 1, MEC are glandular cells containing functionally distinct basolateral and apical plasma membrane domains. The basolateral plasma membrane is the site of the uptake of blood-borne milk constituents such as cholesterol. As mentioned above, cholesterol in blood circulates bound to intestinal chylomicrons or hepatic VLDL, LDL and HDL. Mammary tissues, especially in the lactating state, exhibit enzymatic activities that promote the uptake of circulating cholesterol. It has been shown in rat mammary gland tissues that lipoprotein lipase (LPL) is a key enzyme involved in chylomicron and VLDL triglyceride hydrolysis and the subsequent uptake of free cholesterol and cholesteryl esters [36-39]. Moreover, LPL activity has been found in secretory MEC (not depicted) and in milk [39]. LPL is synthesized in parenchymal tissues including mammary epithelium, but the enzyme is then translocated into the blood vessels where its functional form is found at the surface of vascular endothelium (for review see [40]). The LDL receptor-related protein (LRP) represents an endocytic receptor that is expressed in several tissues. LRP is a member of the LDL receptor family that plays roles in various biological processes such as lipoprotein metabolism. It has been reported that LRP, which shows high similarity with the $\alpha 2$-microglobulin receptor, recognizes several ligands including VLDL or LDL transporting cholesterol [41]. The uptake of cholesterol is also a receptor-mediated process that involves the LDL receptor and scavenger receptor class B type I (SR-BI), respectively. A study in mice showed that LDL binds to the LDL receptor, and the complex is internalized by receptor-mediated endocytosis via clathrin-coated vesicles. LDL particles dissociate from the receptors, which are recycled back to the cell surface. The degradation of the protein constituent of the LDL allows the uptake of contained cholesteryl esters and free cholesterol from circulating LDL remnants [42] (Fig. 1). The presence of SR-BI in mammary gland tissues has been demonstrated, and it is supposed to play a role in mediating the uptake of cholesterol from HDL [43]. In addition to the abovementioned mechanisms, cholesterol uptake is likely to occur also by diffusion across the basolateral membrane. Hence, when primary MEC were loaded in vitro with ${ }^{3} \mathrm{H}$-cholesterol without specific cyclodextrin carriers such as methyl- $\beta$-cyclodextrin or lipoproteins, an uptake of isotope cholesterol was found [44]. An additional transport mechanism which implies a facilitated passage of cholesterol across the plasma membrane by cytosolic transporters such as steroidogenic acute regulatory protein (StAR) exhibiting high binding affinity for cholesterol is also possible [45].

\section{Mechanisms of Intracellular Cholesterol Transport}

Cholesterol is taken up either as esterified or non-esterified molecule, and is compartmentalized in cytosolic organelles through the action of enzymes and intracellular transporters. In all cells (polarized or non-polarized) cholesterol trafficking is critical for the proper distribution of intracellular cholesterol. The fundamental transport pathways involved in intracellular trafficking of cholesterol are described in detail below.

\section{Cholesterol Transport Across Membranes of the Endoplasmic Reticulum}

An important cellular process mediating the intracellular transport of cholesterol is the biosynthetic secretory pathway. The endoplasmic reticulum (ER) is the site of cholesterol synthesis, and different physiological mechanisms exist to keep the steady-state content of cholesterol in the ER membrane low. Acyl-coenzyme A: cholesterol acyltransferase (ACAT) is an ER-associated enzyme, which exists in two isoforms, type 1 and 2. In mammalian cells, ACAT catalyzes the esterification of free cholesterol to cholesteryl esters and its storage as cytoplasmic lipid droplets (CLD) when its level is above the threshold [46]. It has been shown that mammary tissues contain ACAT activity $[47,48]$. This supports a role of ACAT in the esterification process of free cholesterol obtained from circulating carriers and its storage as cholesteryl esters, 
which are then released into milk by secretion. Studies in rats showed variable ACAT activity between lactation and pregnancy, and a correlation between ACAT activity and cholesteryl ester content was found [47, 49]. It was also demonstrated that ACAT activity of microsomal preparations from mammary gland tissues increased by more than $80 \%$ after supplementation with unesterified cholesterol [47, 49]. Recent studies in our laboratories using primary bovine MEC revealed that inhibition of ACAT using a commercial antagonist (CI-976) resulted in an elevated cholesterol efflux potentially due to the subsequent increase in the pool of unesterified cholesterol available for efflux (unpublished data). Sustained loading of MEC with free cholesterol seems to increase the cellular accumulation of cholesteryl esters [44].

\section{Cholesterol Transport Across Endosomal Membranes and Intracellular Trafficking}

Intracellular cholesterol trafficking relies on the actions of enzymes as well as intracellular transporters expressed in the mammary tissue, and represents an important step towards the release of cholesterol into milk. Studies in rats and ruminants showed that distinct cholesterol esters hydrolases, i.e. lysosomal acid lipase (LAL), cholesteryl ester hydrolase (CEH), and hormone-sensitive lipase (HSL), are expressed in mammary tissues including the lactating state when milk secretion occurs [50-53]. As illustrated in the model of Fig. 1, cholesteryl esters taken up from circulating LDL are supposed to be directed to the endosomes from where they are transported towards cellular compartments including the apical plasma membrane which is in contact with the alveolar milk [54]. The trafficking of cholesteryl esters taken up from circulating LDL involves i) the cleavage of the cholesteryl esters by LAL in the lysosomes ii) the binding of the free cholesterol by the lysosomal membrane transporter NiemannPick type C (NPC) type 2, iii) the transfer to NPC1, and iiii) the final export to other cellular compartments for storage or release into milk (Fig. 1). Cholesteryl esters that are stored in CLD after esterification by ACAT, or that entered the MEC by SR-B1-mediated uptake at the basolateral membrane, are hydrolyzed to produce free cholesterol susceptible to be transferred into the milk. The key role of NPC in mediating the inter-membrane cholesterol trafficking [55] became evident when mutations of the NPC gene were associated with Niemann-Pick type $\mathrm{C}$ disease, a disorder characterized by the accumulation of cholesterol and glycosphingolipids in vital organs [56]. Recently, gene expression studies in bovine mammary tissues showed a differential abundance of mRNA transcripts of NPC1 throughout the pregnancy-lactation cycle. Interestingly, NPC1 mRNA levels were significantly reduced during the dry period, but were subsequently increased after parturition [57]. These findings suggest an involvement of NPC1 in cholesterol trafficking to adapt to the requirements for milk secretion. Data derived from MEC are lacking, but it has been reported that plasma membrane cholesterol in other polarized cells is higher in the apical than basolateral membrane [6]. The trafficking of cholesterol synthesized in the ER involve non-vesicular and vesicular transport processes [58, 59] that ultimately cargo cholesterol to the plasma membrane for its release into milk. The oxysterol-binding protein (OSBP) and OSBP-related proteins (ORP) are likely to be predominant pathways for cholesterol transfer into and out of the ER in MEC [59-61]. Type 2 ORP over-expression in HeLa cells showed enhanced transfer of cholesterol from the ER to the plasma membrane similarly as in CHO (Chinesehamster ovary) cells constitutively expressing ORP [62]. The vesicle-mediated secretory pathway through the trans-Golgi network (not illustrated in Fig. 1) is a likely route for cholesterol trafficking from the ER towards other cellular compartments including the apical plasma membrane. Interestingly, the treatment of polarized hepatocytes with brefeldin A, an inhibitor of transport from the ER to the Golgi network, did not significantly delay the transfer of newly synthesized cholesterol from the ER to the plasma membrane [63, 64]. It has been also reported that in polarized cells cholesterol content increases from low levels in the ER to intermediate levels in the trans-Golgi network, and is highest in the plasma membrane [59].

\section{Mechanisms of Cholesterol Efflux at the Apical Plasma Membrane}

\section{Mammary Cell Specific Secretion Mode}

As illustrated in Fig. 1, cholesterol transport into milk involves a specific secretion mode inherent to MEC, which implies a continuous energy-independent transport of cholesterol contained in milk lipid droplets [65-68]. Milk lipids are secreted by alveolar MEC as emulsified globules surrounded by a protein-rich polar lipid coat called the milk lipid droplet membrane. The milk lipid droplets are synthesized in the ER and migrate towards the apical membrane as they develop and mature (Fig. 1) [65, 69]. At the apical plasma membrane domain, lipid droplets are progressively enveloped by the apical plasma membrane and pinched off into the alveolar lumen. A detailed overview on lipid transport mechanisms in the mammary gland and their importance for milk secretion is also given in the article of McManaman in the present issue. The plasma membrane derivative covering the lipid droplet contains cholesterol and other phospholipid components. It has been demonstrated that approx. $80 \%$ of the total milk cholesterol is found within the membrane surrounding the milk lipid droplet $[69,70]$. Similarly, the major fraction of phospholipids (approx. $60 \%$ of total milk phospholipids) is also derived from the membrane of the milk lipid droplet. The remaining part of both milk cholesterol and phospholipids are 
found in skim milk $[69,70]$. Whether the distribution of cholesterol in different milk fractions is suggestive of the secretory routes has not been specifically addressed yet.

\section{Active Cholesterol Transport}

It is well established that in mammalian cells cholesterol is transported by an energy-consuming mechanism that involves the interaction of specific $\mathrm{ABC}$ transporters with their partners such as a lipid-poor apolipoprotein (apo) A-1 which act as cholesterol acceptors. $\mathrm{ABC}$ transporters are one of the largest families of integral plasma membrane proteins involved in the transport of various substrates including cholesterol and phospholipids across cellular membranes. Seven subfamilies of $A B C$ transporters named from $A$ to $G$ have been identified and characterized so far. They consist of intracellular nucleotide binding domains and trans-membrane domains composed of 6-11 membrane-spanning $\alpha$-helices. ABC transporters are categorized into full transporters when they contain two nucleotide binding domains and two trans-membrane domains (e.g. ABCA1), or half transporters with one nucleotide binding domain and one trans-membrane domain each (e.g. ABCG1). The functional activity of ABC transporters requires the hydrolysis of ATP bound to the intracellular nucleotide binding domains. It is established that $\mathrm{ABC}$ transporters of the subfamily A differ from other $\mathrm{ABC}$ transporters by the presence of two large extracellular domains which exhibit conformational changes required for cholesterol transport following hydrolysis of ATP [71].

The ABC transporter-mediated cholesterol transport process is important in maintaining cellular cholesterol homeostasis as its dysfunction has been associated with the occurrence of various hereditary diseases such as Tangier disease or familial HDL deficiency (mutations in ABCA1, [19, 72]), pulmonary surfactant deficiency in newborns (ABCA3, [73]), or Stargardt disease 1 (ABCA4) (for review see [74]). ABCA7, another member of the A subfamily, is a full transporter with highest homology to ABCA1 that has been identified at the plasma membrane [75], and in vitro studies revealed that $\mathrm{ABCA} 7$ promotes the efflux of cellular phospholipids onto lipoproteins [76]. Consistently, ABCA7 nullmice show reduced HDL levels and alterations in adipose mass [77, 78].

A prerequisite for an involvement of $\mathrm{ABC}$ proteins in transcellular cholesterol transport in the mammary gland is their plasma membrane localization in mammary tissue. Interestingly, studies by Reinhardt and Lippolis [79] and Mani et al. [67] identified the presence of $\mathrm{ABC}$ transporter proteins on the plasma membrane covering the milk fat globule prepared from human and cow milk, supporting their potential role in cholesterol transfer into milk. In this context, $\mathrm{ABC}$ transporters belonging to the subfamilies $A$ and $G$ seem to represent the most interesting candidates as their implication in cholesterol transport in other polarized cell types had been repeatedly shown $[80,81]$.

Besides $\mathrm{ABC}$ transporters, a wide variety of proteins such as butyrophilin, xanthine oxidase, or adipophilin are found in the membrane enveloping the lipid droplets. In a recent study, the proteomic characterization of human milk fat globule (MFG) membrane has identified the presence of more than 190 proteins which are important for diverse cellular functions such as cellular growth, immune function, or cell signaling $[82,83]$. Comparative analysis showed that the protein expression in MFG membrane prepared from mature milk is associated with the progression of lactation [83]. For instance, it has been shown that butyrophilin, xanthine oxidase and adipophilin which form a complex implicated in lipid droplet formation and secretion [84-86] were individually upregulated in the membrane of MFG prepared from mature milk as compared to colostrum [83]. In contrast, the expression of the cholesterol acceptor apoA-I was down-regulated [3]. ABCA1 and AGCG1 protein have been identified in the MFG membrane isolated from mature milk, strongly suggesting the presence of these transporters at the apical membrane [67]. However, it is currently unclear as to whether those energy-consuming transporters are operational in the MFG since they would require cellular ATP.

\section{Expression and Localization of ABCA Transporters}

Studies investigating the expression of ABCA transporters in the mammary gland are scarce. Comparing the abundance of ABCA1 among human tissues, it was shown that ABCA1 mRNA transcripts were higher in placenta, liver, lung, adrenal glands and foetal tissues than in mammary gland [87]. A similar pattern has also been reported by other investigators who indicated a low expression level of ABCA1 mRNA in bovine mammary tissues as compared to lung or liver [88]. Mani et al. [4] compared the expression of ABCA1 and ABCA7 among three mammalian species. The mRNA expression of ABCA1 was significantly higher in non-lactating than in lactating murine mammary tissues. However, ABCA7 mRNA abundance was similar between these two functional states of the mammary gland. In bovine, however, the mRNA expression of ABCA1 and ABCA7 was significantly greater in nonlactating than in lactating mammary tissues. In this context it should be noted that depending on the developmental and functional stages, the mammary gland contains variable amounts of adipocytes [89], which are known to express also cholesterol transporters [90]. In general, these findings suggest a variable importance of the transporters in cholesterol transport during nonlactating and lactating states of the mammary gland [4, 57, 67]. An inverse association between the mRNA levels 
of NPC1 and ABCA1 during the pregnancy-lactation cycle was observed. In fact, an increase of ABCA1 during the non-lactating phase was paralleled by a marked decrease of the mRNA level of NPC1 [57].

As summarized in Table 3 and Fig. 2, immunohistochemical studies have identified the cellular and sub-cellular localizations of $\mathrm{ABCA}$ transporters in mammary tissues and cells. The comparison of ABCA1 localization among mouse, human and bovine mammary gland tissues obtained at different physiological states revealed that this protein was localized at both basal and apical sides of secretory mammary cells [4]. $\mathrm{ABCA} 1$ and $\mathrm{ABCA} 7$ proteins were stained in the alveolar and ductal epithelium in lactating human mammary tissues (with higher intensity for $\mathrm{ABCA} 1$ than $\mathrm{ABCA} 7$ ). In non-lactating mammary tissue $\mathrm{ABCA} 1$ and $\mathrm{ABCA} 7$ were also detected in endothelial cells and adipocytes (Table 3 and [4]). The presence of ABCA1 in murine and bovine mammary tissues supports the assumption that the transporter plays a role in lipid storage and possibly in their transfer across the mammary epithelium. As indicated in Table 3, ABCA1 and ABCA7 positive staining was completely absent in MEC of nonlactating murine mammary tissue while ABCA1-positive mammary adipocytes were detected [4]. In lactating murine tissues ABCA1 and ABCA7 positive cells were mainly detected in the glandular epithelium with diffuse cytoplasmic

Table 3 Species-based protein localization of candidate ABC transporters in various mammary cell types

\begin{tabular}{|c|c|c|c|c|c|c|}
\hline \multirow{2}{*}{$\begin{array}{l}\text { Species/Protein } \\
\text { Cell type }\end{array}$} & \multicolumn{2}{|c|}{ Non-lactating ${ }^{1}$} & \multicolumn{2}{|c|}{ Non-lactating $^{2}$} & \multicolumn{2}{|c|}{ Lactation } \\
\hline & MEC & $\mathrm{AD}$ & MEC & $\mathrm{AD}$ & MEC & $\mathrm{AD}$ \\
\hline \multicolumn{7}{|l|}{ Homo sapiens } \\
\hline ABCA1 & ++ & $+/-$ & ++ & + & +++ & + \\
\hline ABCG1 & - & + & - & + & + & + \\
\hline \multirow[t]{3}{*}{ ABCA7 } & + & - & ++ & $-/+$ & ++ & $-/+$ \\
\hline & \multicolumn{2}{|c|}{ Non-lactating } & \multicolumn{2}{|c|}{ Early lactation } & \multicolumn{2}{|c|}{ Mid-lactation } \\
\hline & MEC & $\mathrm{AD}$ & MEC & $\mathrm{AD}$ & MEC & $\mathrm{AD}$ \\
\hline \multicolumn{7}{|l|}{ Mus musculus } \\
\hline ABCA1 & - & +++ & ++ & +++ & ++ & +++ \\
\hline ABCG1 & - & - & + & ++ & ++ & $+/-$ \\
\hline \multirow[t]{3}{*}{$\mathrm{ABCA} 7$} & - & - & ++ & +++ & + & + \\
\hline & \multicolumn{2}{|c|}{ Non-lactating } & \multicolumn{2}{|c|}{ Early lactation } & \multicolumn{2}{|c|}{ Mid-lactation } \\
\hline & MEC & $\mathrm{SC}$ & MEC & $\mathrm{SC}$ & MEC & $\mathrm{SC}$ \\
\hline \multicolumn{7}{|l|}{ Bos taurus } \\
\hline ABCA1 & +++ & + & +++ & - & +++ & + \\
\hline ABCG1 & + & - & ++ & - & ++ & - \\
\hline
\end{tabular}

Estimated expression grade for different mammary cell types is indicated as ' - ', absent; ' $-/+$ ', weak staining intensity; and ' + ' to ' +++ ', low- to high-staining intensity. Non-lactating (1) = ante-menopausal; Non-lactating (2) = post-menopausal. This table has been adapted from [4] and is published with permission from the American Physiological Society

$M E C$ alveolar mammary epithelial cells, $A D$ mammary adipocytes, $S C$ stromal cells distribution. In addition, positive staining for ABCA1 and ABCA7 was localized in mammary adipocytes of lactating murine mammary tissues. To date studies analyzing the expression of these cholesterol transporters in pure MEC instead of whole mammary tissue which consists of various different cell types are still missing.

Studies comparing healthy and diseased human breast tissues showed a strong expression of ABCA1 and ABCA3 in normal mammary gland epithelium. Moreover, intracellular localization of ABCA1 has been identified in human breast cancer tissues [91]. With respect to the subcellular distribution ABCA1 has been detected mainly on the plasma membrane and some intracellular compartments like the Golgi network and recycling endosomes [92].

\section{Expression and Localization of ABCG Transporters}

Among transporters of this sub-family ABCG1 shows structural and expressional similarities with ABCA1. It is established that ABCG1 mediates the cellular cholesterol efflux to HDL but not to lipid-poor apoA-I. As shown in Table 3 and Fig. 3, the mRNA transcripts encoding ABCG1 and corresponding protein were identified in mouse MEC and mammary adipocytes [4]. The expression level of ABCG1 in mammary adipocytes was persistant throughout lactation and pregnancy whereas it was absent in MEC of human and murine non-lactating mammary tissues [4], suggesting a potential role of ABCG1 in regulating cholesterol storage in mammary tissues. In contrast to the expression pattern in mouse mammary gland tissues, ABCG1 was localized in the mammary epithelium of both non-lactating and lactating bovine mammary tissues [4]. Generally, the expression pattern in the mammary gland may support a potential role of ABCG1 in lipid transport. This is in line with studies in other cell types suggesting that ABCG1 plays a role in cholesterol movements and trafficking to the plasma membrane [93, 94].

The mRNA transcripts encoding ABCG5 and ABCG8 were identified with relatively low abundance in bovine mammary gland tissues in few previous studies $[88,95]$, suggesting that these obligate heterodimers might play a minor role in cholesterol transport in this tissue. However, the protein expression and functional activity of ABCG5 and ABCG8 in mammary tissue has not been elucidated so far. These two transporters were found to be important in the transport of dietary cholesterol and other sterols in the liver and intestine [96-98]. Mutations in either ABCG5 or ABCG8 cause sitosterolemia, a rare autosomal recessive disorder characterized by accumulation of both plant-derived sterols and animalderived sterols (cholesterol) in plasma and tissues, leading to the development of xanthomas [99]. 


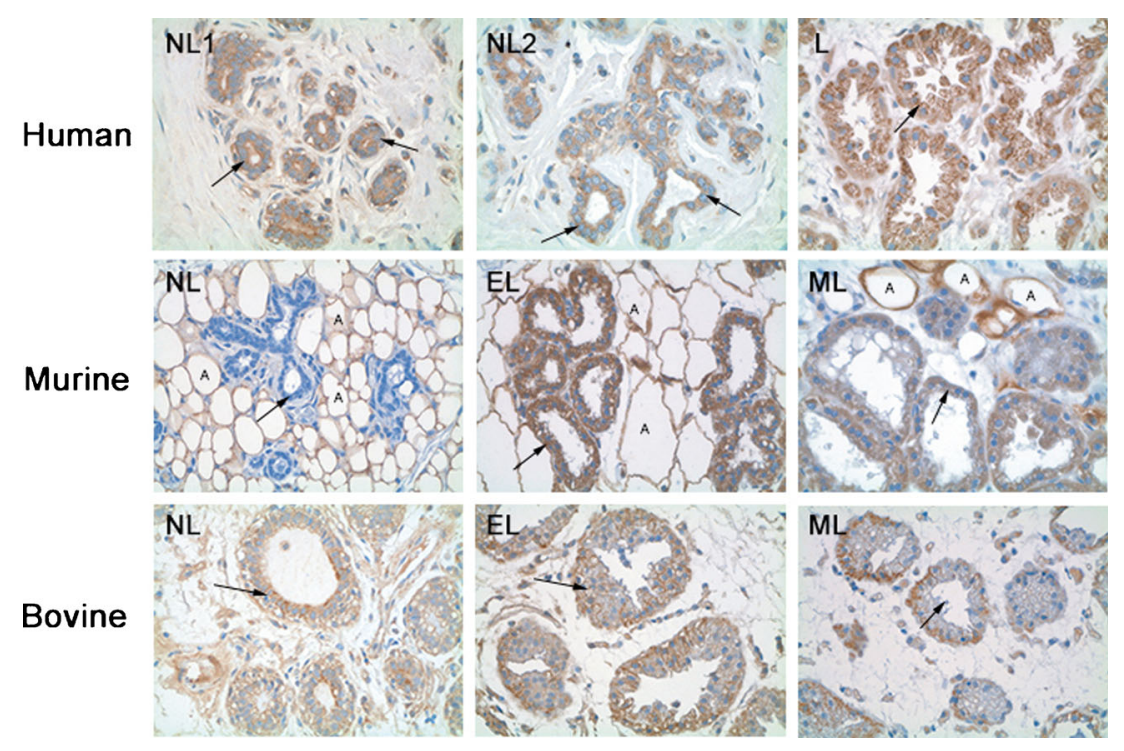

Fig. 2 Immunohistological localization of the cholesterol transporter ABCA1 in non-lactating and lactating mammary tissues of different species. Mammary gland sections of human, murine and bovine origin were stained with a specific antibody against ABCA1. For details on the methodology see [4]. In human breast samples NL1 and NL2 indicate the non-lactating antemenopausal and postmenopausal state, respectively; $L$ lactating. Murine and bovine samples: $N L$ non-lactating, $E L$ early lactation (mouse: 1-6 days after parturition; cow: day 14 of lactation), $M L$ mid-lactation mouse: 9-12 days after parturition; cow: day 88 of lactation), $A$ adipocyte. Black arrows indicate mammary epithelial cells. Magnification: $\times 40$. Data are adapted from [4] with permission from the American Physiological Society

\section{Diffusion of Cholesterol}

Milk contains diverse soluble proteins such as albumins which bind cholesterol and therefore could potentially act as acceptors during the transfer across the apical membrane. Accordingly, it was observed that primary bovine MEC preloaded with ${ }^{3} \mathrm{H}$-cholesterol were able to efflux greater amounts of cholesterol when the culture medium was supplemented with bovine serum albumin, supporting a possible carrier-mediated diffusion process for cholesterol. Thereby cholesterol efflux in the presence of bovine serum albumin was not inhibited by micromolar concentrations of probucol, an inhibitor of ABCA1 (unpublished data). On the other hand, when primary bovine MEC were preloaded with ${ }^{3} \mathrm{H}$-cholesterol retrograde diffusion of the isotope into the medium was observed even in the absence of cholesterol acceptor [44], suggesting passive diffusion of cholesterol across the plasma membrane. In this context, some studies have reported that cholesterol can pass through the plasma membrane by passive diffusion through the aqueous phase of the surroundings $[100,101]$. Thus, as depicted in Fig. 1, diffusion of cholesterol likely represents an additional transfer mechanism of cholesterol into milk.

\section{Recent Advances in Investigating Cholesterol Binding and Transport in the Mammary Gland}

In general, the methods to study cholesterol transport and distribution in biological membranes are based on the measurement of radioactively labeled cholesterol (e.g. with ${ }^{3} \mathrm{H},{ }^{14} \mathrm{C}$, etc.) or fluorescent cholesterol [54]. With respect to the use of fluorescent cholesterol derivatives, it was initially suspected that the fluorophore might change the properties of cholesterol and therefore impairs its transport and distribution among cellular membranes [102]. However, relatively recent studies comparing the transport of ${ }^{3} \mathrm{H}$ cholesterol and BODIPYcholesterol in $\mathrm{J} 774$ cells demonstrated that BODIPYcholesterol provides an efficient measurement of cholesterol efflux compared with ${ }^{3} \mathrm{H}$-cholesterol [103] suggesting that this fluorescent compound is also suitable for cholesterol studies in MEC. The transport and distribution of de novo synthesized cholesterol in the plasma membrane can be estimated by loading cells with radioactively labeled acetate and then measuring the resulting amount of radioactive cholesterol in the plasma membrane. Cholesterol transport and distribution can be estimated by using the fluorescent detergent filipin which binds specifically to unesterified cholesterol [104]. In a study using bovine mammary tissues and isolated milk fat globules, filipin has already been efficiently used to stain the milk fat globule membrane enveloping the core containing triglycerides [67]. Other methods can be used to quantify total cholesterol in cells and tissues. They include the measurement of cellular cholesterol by gas chromatography - mass spectrometry [105] or by colorimetric enzymatic assays [44]. The three-dimensional culture system where MEC grow on coated surface and form milksecreting clusters (i.e. mammospheres) may also represent an interesting experimental system to study cholesterol transport. This model has been already applied to mouse primary 
mammary cells [106] to investigate ${ }^{45} \mathrm{Ca}$ transport in MEC and could presumably be adapted for cholesterol transport studies.

A scintillation proximity assay has been developed to study endosomal trafficking of radiolabeled cholesterol in living non-polarized cells [107]. This methodological approach could be also used to study the involved transport in mammary cells because intracellular cholesterol transport pathways are similar between polarized and unpolarized cells. The difficulty regarding the quantitative measurement of cholesterol in specific cellular compartments is based on the fact that, as described above, cholesterol can diffuse from the plasma membrane, undergoes intracellular trafficking, and can be stored in esterified or unesterified pools which are distributed in different intracellular compartments.

In a recent study [44], the kinetics of cholesterol uptake and processing by MEC as well as the binding determinants of the components of the HDL cholesterol transport system (cholesterol and apoA-I) have been determined in plasma membrane microsomal preparations prepared from lactating and nonlactating mammary gland tissues. It has been shown that in vitro cholesterol transport into and out of the cells has been characterized by an inversion point, which has an impact on the levels of cholesterol transported, compartmentalized, and released from the cells. By considering additionally the binding properties of the constituents of the HDL transport system, a robust and comparably fast cell-based cholesterol efflux assay was established and used to decipher the directionality of cholesterol transport in MEC. In this context, it was shown that, similarly to other cell types, cholesterol transport in MEC involves a direct interaction of ABCA1 with apoA-I. The binding of ${ }^{125} \mathrm{I}$-apoA-I to isolated plasma membrane vesicles was of high affinity and could be competitively inhibited by an ABCA1 inhibitor. At steady-state conditions the transport of cholesterol appeared to be more pronounced at the basolateral domain of the plasma membrane as compared to the apical side [44].

Recently, Sorg and coworkers [108] have shown that primary MEC used for functional in vitro analyses can also be successfully isolated from milk. The gene expression analysis of traits (e.g. prolactin receptor) and functional investigations (e.g. cholesterol efflux) performed with those cell preparations indicated that MEC isolated from milk are comparable, and in some aspects even advantageous to MEC prepared from mammary tissue [108]. Hence, the isolation of MEC using milk seemed to significantly lower the contamination with other mammary cell types (e.g. fibroblasts).

\section{Regulation of Cholesterol Transport and Synthesis}

In mammary tissues, the homeostatic control of lipids including cholesterol is exerted both through the regulation of the de novo synthesis of lipids and via the control of uptake and efflux [109-111]. The regulation of cholesterol uptake, intracellular transport, and efflux in the mammary gland involves the action of cellular enzymes and transcription factors. It has been shown that mammary tissues express 3-hydroxy-3-methylglutaryl-CoA (HMG-CoA) reductase, which is a ratelimiting enzyme in the de novo synthesis of cholesterol from acetate via the mevalonate pathway. Various studies reported the expression of HMG-CoA reductase in mammary tissues and its regulatory mechanisms [112-114]. Hormones promoting intracellular increase of cAMP stimulate the activity of HMG-CoA reductase and the uptake of LDL-cholesterol. With the increase of intracellular cholesterol, the expression of the LDL receptor and the activity of both HMG-CoA reductase and LAL are suppressed, whereas ACAT is induced. These changes are accompanied by decreasing cholesterol uptake, synthesis and de-esterification.

When intracellular cholesterol concentrations are low, the situation is reversed. Sterol response element binding proteins (SREBPs) 1 and 2 are important regulators of lipid synthesis. They bind the sterol responsive element located in the promoter region of the response genes [115]. SREBP-1c activates genes involved in triglyceride synthesis when cholesterol levels are high, whereas SREBP2 promotes, among other pathways, the expression of cholesterol synthetic genes when cellular cholesterol levels are low. Expression studies using bovine mammary tissues revealed that mRNA transcripts encoding SREBP1 and SREBP2 were markedly suppressed at the end of the previous lactation, and were strongly enhanced after parturition and throughout lactation indicating the critical importance of SREBPs in maintaining a balanced lipid content in the milk [57].

An increase of intracellular cholesterol levels is accompanied by an enhanced synthesis of oxysterols, which are oxydized derivatives of cholesterol playing important functions in lipid metabolism [116, 117]. They act as agonists for the liver X receptors (LXRs), cytosol-located transcription factors, which exist as $\alpha$ and $\beta$ isoforms [118]. It is considered that $\operatorname{LXR} \alpha$ acts as a regulator of milk fat synthesis as its expression level was increased during the transition from pregnancy to lactation [57]. Furthermore, stimulation of bovine MEC with a synthetic agonist of LXR $\alpha$ (TO901317) led to an increase of de novo fatty acid synthesis [119]. Besides, it has been shown that $\mathrm{LXR} \alpha$ regulates the transcription and expression of cholesterol transporters such as ABCA1 [120]. Recent findings demonstrated that stimulation of primary bovine MEC with TO901317 increased both the mRNA abundance of $\mathrm{ABCA} 1$ and the cellular efflux of ${ }^{3} \mathrm{H}$-cholesterol (authors' unpublished observation).

Other regulatory genes influencing cholesterol transport in the mammary gland include the nuclear receptor peroxisome proliferator-activated receptors (PPARs), which act as 
nutritional sensors regulating a variety of homeostatic functions including metabolism, inflammation and development [115]. These nuclear receptors exist as isoforms $\alpha, \gamma$ and $\beta / \delta$ which are expressed in a variety of tissues and cells including the mammary gland and mammary cell line MAC-T [114]. The contribution of PPARs in regulating milk lipid synthesis across species has been discussed, and it is assumed that PPAR $\gamma$ plays a role in controlling the milk lipids in ruminants, but probably not in certain other species such as mouse [121, 122]. Regarding the effect on cholesterol synthesis, PPAR $\alpha$ was shown to up-regulate the de novo synthesis by altering the activity of HMG-CoA reductase [123].

PPAR $\alpha$ is a main metabolic regulator for catabolism whereas PPAR $\gamma$ regulates anabolism or storage [115]. PPAR agonists can activate PPAR $\alpha$ which in turn activates the transcription of retinoid X receptor and LXR genes in macrophages, leading to enhanced transcription of $\mathrm{ABCA} 1$ and ABCG1 [124]. A role of PPAR $\gamma$ in the regulation of cholesterol transport in mammary tissues has been suggested by studies revealing a differential expression pattern of this gene during the pregnancy-lactation cycle [57].

In addition to the abovementioned regulatory factors, the expression and activity of lipid transporters and their modulators are tightly regulated by hormones, which are typically altered during the pregnancy-lactation cycle. It is well accepted that prolactin is a regulator of the synthesis of milk components. In rats a marked reduction of mammary LPL activity, an enzyme implicated in cholesterol uptake (Fig. 1), was observed after hypophysectomy which was abolished after prolactin injection [125], supporting a potential involvement of prolactin in cholesterol uptake. However, a more complex hormonal regulation of mammary LPL activity was also postulated involving additional hormones such as growth hormone and its related growth factors [126, 127]. Interestingly, the transcription factor prolactin regulatory element binding (PREB) is present in the promoter region of ABCA1 [128], and transcripts of PREB were found in human and bovine MEC (unpublished data).

Recent in vitro studies in our laboratories also revealed that primary bovine MEC show increased ABCA1-mediated cholesterol efflux after stimulation with hydrocortisone, insulin, estradiol and progesterone (unpublished data). In addition, treatment with the synthetic agonist of cyclic AMP (forskolin) enhanced ABCA1-mediated cholesterol efflux (unpublished data). Furthermore, it has been observed that ABCA1-mediated cholesterol efflux in primary bovine MEC is suppressed by treatment with inhibitors of JAK-2 and MAPK, two effector proteins amongst others, which are downstream targeted by activation of the prolactin receptor, suggesting a potentially regulatory effect of prolactin on the transporter. As depicted in Fig. 4, future investigations should be addressed to decipher the potential crosstalk between ABCA1 and hormones such as prolactin and to clarify potential interplays between transporters, hormones and signaling pathways in the mammary gland. This is of particular interest as signaling pathways and downstream targets for insulin, glucocorticoids and progesterone are not well understood [129].

\section{Mammary Gland Function and Reverse Cholesterol Transport}

Cellular cholesterol efflux, its loading onto lipid-poor apoA-I or other cholesterol acceptors, and the subsequent transport via HDL particles to the liver is an important physiological mechanism termed reverse cholesterol transport. It allows the retrograde transport of cholesterol from peripheral cells such as macrophages to the liver for excretion, and involves the contribution of cholesterol transporters such as ABCA1 [19]. Severe disturbances of this transport mechanism lead to an intracellular accumulation of cholesterol in form of cholesteryl esters and to the formation of foam cells, thereby accelerating the development of atherosclerosis $[130,131]$. The initial process of foam cell formation is characterized by a migration of blood monocytes into the vascular wall followed by their differentiation into macrophages [132]. Cellular cholesterol homeostasis depends on the equilibrium between diverse important cellular processes. These include i) the uptake of cholesterol by receptor-mediated pathways, ii) de novo synthesis via the HMG-CoA reductase pathway, iii) the controlled esterification of free cholesterol mediated by ACAT, and its hydrolysis by $\mathrm{CEH}$, and iv) the cellular efflux of free cholesterol by cholesterol transporters such as ABCA1. Despite the obvious histological and functional differences between MEC and macrophages, it should be considered, however, that the entire machinery of receptors, enzymes and transporters implicated in reverse cholesterol transport is also expressed in MEC. Gene expression measurements of ABCA1 at different stages of the pregnancy-lactation cycle showed that ABCA1 mRNA levels were significantly higher in non-lactating as compared to lactating mammary tissues [57]. However, the reversible adipocyte-to-epithelium and epithelium-toadipocyte trans-differentiation occurring in mammary tissues during lactation and non-lactation, respectively, variably influence the adipocyte content of the tissue [89]. Data reported by Mani and colleagues have not been normalized for this aspect, thus the presence of substantial amounts of adipocytes in the non-lactating mammary tissue is likely to contribute to the increased ABCA1 mRNA abundance found in nonlactating total mammary tissue. Nonetheless, localization studies and functional investigations in bovine mammary tissues and cells showed that ABCA1 protein is present on the plasma membrane of mammary secretory cells, and that ABCA1-mediated cholesterol efflux occurs both at the apical membrane facing the alveolar milk and at the basolateral 


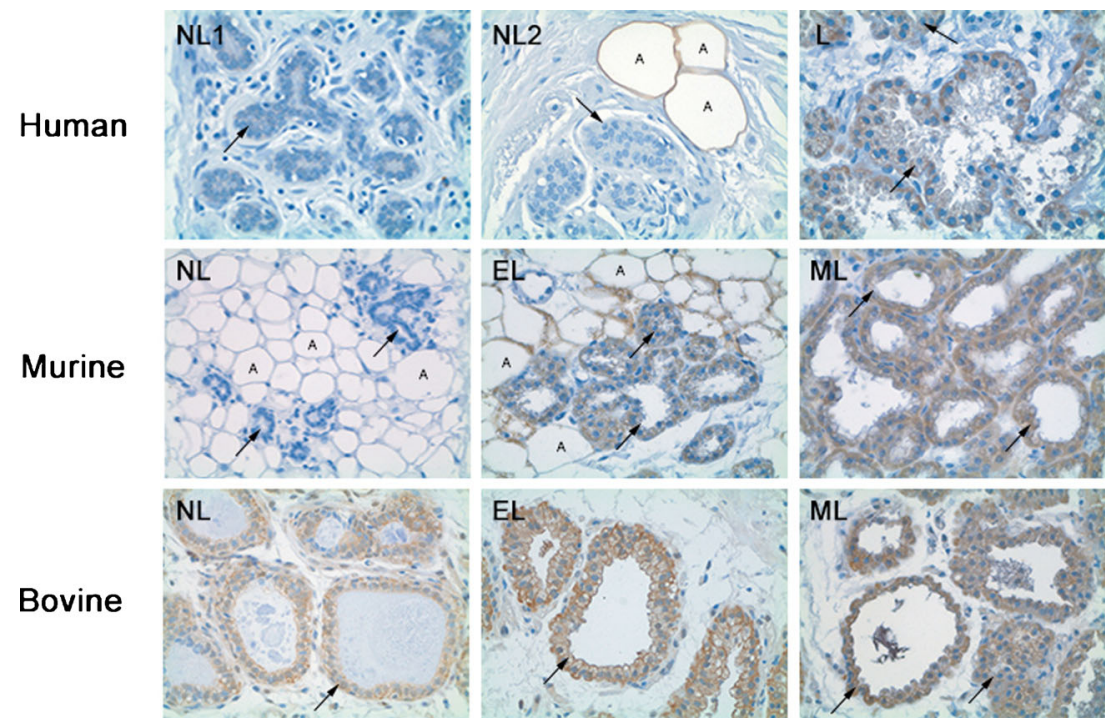

Fig. 3 Immunohistochemical localization of ABCG1 in non-lactating and lactating mammary tissues of different species. Mammary gland sections of human, murine and bovine origin were stained with a specific antibody against ABCG1. For details on the methodology see [4]. In human breast samples NL1 and NL2 indicate the non-lactating antemenopausal and postmenopausal state, respectively; $L$ lactating.
Murine and bovine samples: $N L$ non-lactating, $E L$ early lactation (mouse: 1-6 days after parturition; cow: day 14 of lactation), $M L$ mid-lactation mouse: 9-12 days after parturition; cow: day 88 of lactation), $A$ adipocyte. Black arrows indicate mammary epithelial cells. Magnification: $\times$ 40. Data are adapted from [4] with permission from the American Physiological Society membrane oriented towards the bloodstream. Indeed, in steady-state culture conditions cholesterol efflux was more pronounced at the basolateral side than at the apical membrane [44]. Therefore, it appears likely that MEC release cholesterol back into the blood circulation when milk synthetic activity is markedly reduced (or suppressed) to avoid intracellular cholesterol accumulation (e.g. during non-lactating periods). In conclusion, the functional stage of the mammary gland and the herewith associated differential activity of cholesterol transporters may have a yet underestimated impact on blood cholesterol levels, HDL formation and reverse cholesterol transport.

\section{Summary, Conclusions, and Research Perspectives}

The present review has summarized the state-of-art knowledge on cholesterol transport mechanisms and regulation in the mammary gland, and has briefly discussed the multifaceted role of cholesterol with respect to health and disease. So far, data on cholesterol transport in the mammary gland are essentially derived from expressional studies suggesting the importance of enzymes, receptors, and transporters in the regulation of cholesterol homeostasis in mammary tissues. Based on these findings, the implication of ABC and NPC transporters, lipases, ACAT, and lipoprotein receptors such as LDL or SR-B1 in cholesterol uptake, trafficking, storage, and release into milk has been highlighted. Regarding $\mathrm{ABC}$ transporters, the role of $\mathrm{ABCA} 1$ and its interacting partner apoA-I in cholesterol transport in the mammary gland has been the most studied so far, i.e. by using both tissue- and cell-based approaches. Complementary investigations are warranted to clarify the functional role of $A B C G 1$, ABCG5/ABCG8 as well as ABCA7, whose mRNA and/ or protein expression in the mammary tissues have also been reported.

Recent cell-based work on directional aspects suggests that cholesterol transport in MEC is more pronounced at the basolateral side implying that cholesterol transfer in the mammary gland is not a unidirectional process. Accordingly, elucidation of whether the possible reverse cholesterol transport by MEC is a continuous or a stagespecific process is of major importance. Further investigations should take advantage of the already established Transwell ${ }^{\circledR}$ system and test MEC cultured in conditions mimicking in vivo physiological stages to determine 1) if cholesterol is predominantly transported either via energydependent or energy-independent mechanisms, 2) whether these processes, including the transport orientation, are dependent of the physiological and functional stage of the mammary gland, 3) how key hormones specific for the pregnancy-lactation cycle affect these processes. Threedimensional cell culture systems and the use of labeled (including fluorescent) cholesterol derivatives to investigate cholesterol transport in MEC could majorly improve our understanding of mechanisms determining the milk composition. In this context one of the crucial issues faced by the researchers is associated with the heterogeneity of cell types present in primary cell preparations, and the difficulty of maintaining highly pure primary MEC cultures 


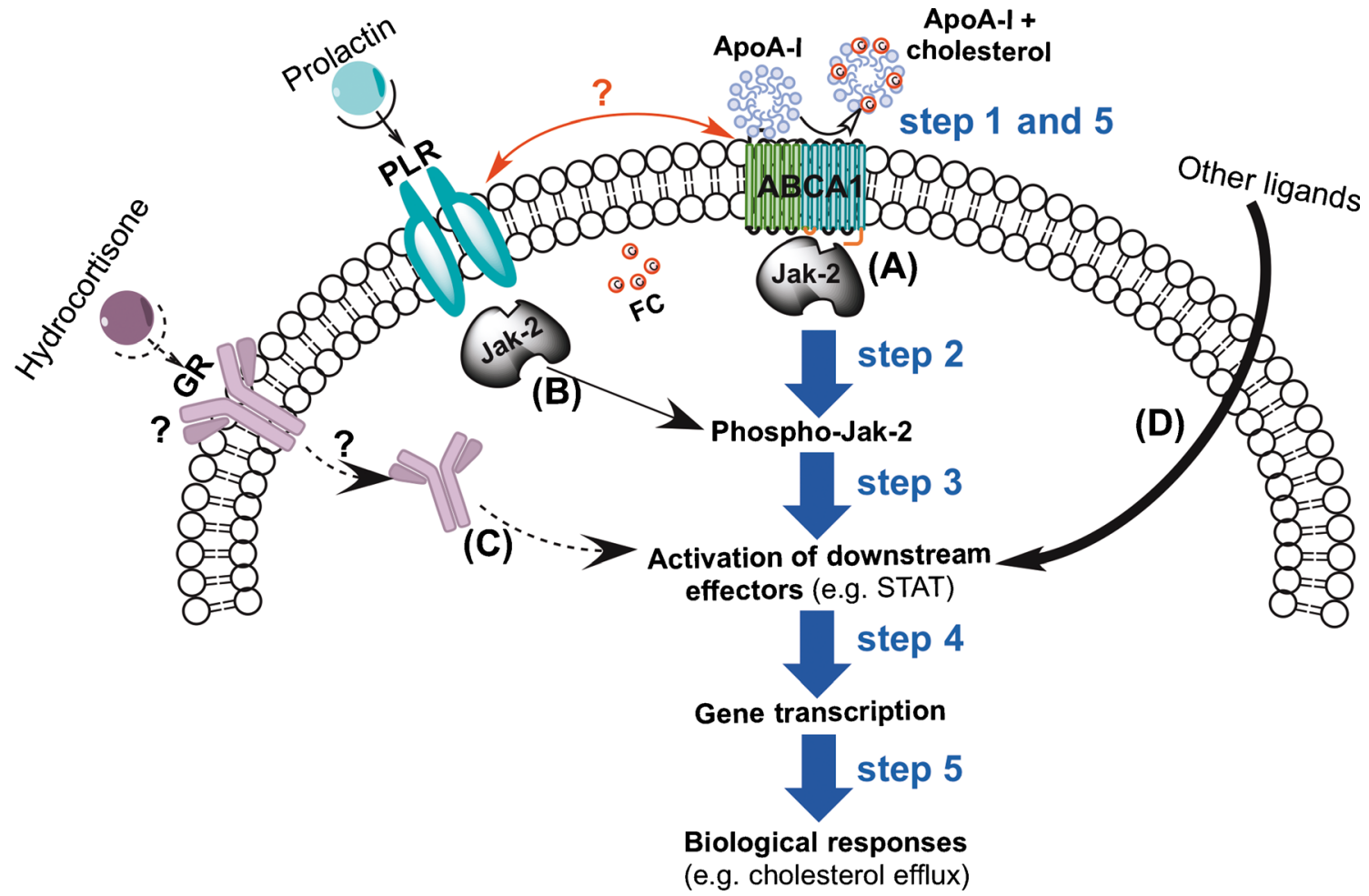

Fig. 4 Potential ABCA1 signaling and crosstalk in mammary epithelial cells (MEC). The main signaling mechanism (A) associated with cholesterol efflux from MEC involves the cell surface interaction of apoA-I with ABCA1 (step 1) that induces autophosphorylation of the ABCA1-associated janus-kinase (Jak)-2 [142] (step 2). The latter activates downstream cytosolic effector proteins such as signal transducer and activator of transcription (STAT) (step 3) which, after dimerization, is translocated into the nucleus to regulate the gene transcription (step 4) followed by the cell biological responses (step 5). Mechanism (B) shows the signaling pathway initiated by prolactin/prolactin receptor (PLR) interaction at the cell surface which involves similar steps as indicated for the apoA-I/ABCA1 signaling

over several passages. In this regard, the use of MEC extracted from milk might be an efficient alternative to MEC isolated from mammary gland tissue.

Among other cell biological aspects, the clarification of intracellular signaling pathways (Fig. 4) associated with the function of $\mathrm{ABC}$ transporters in the mammary gland is of major importance. Such investigations will not only contribute to unravel the molecular mechanisms of cholesterol transport, but also to potentially identify additional biological functions of $\mathrm{ABC}$ proteins beside lipid transfer into milk. Moreover, additional in vivo studies are required to identify to which extent $\mathrm{ABC}$ transporters are crucial to determine the milk cholesterol content. Strategies applicable in this context may derive from genetic models summarized elsewhere [133], which have been previously used in the context of in vivo reverse cholesterol transport studies. For instance, the knockout mouse models of ABCA1 [134], ABCG5/ABCG8 [135], SR-B1 [136], or apoA-I [137] could be used to determine how these proteins affect milk cholesterol content. In addition, our understanding of cholesterol metabolism in the mammary

pathway. However, it has not been investigated so far whether signaling initiated by prolactin has regulatory effects on cholesterol efflux. Additional effects on cholesterol efflux could be initiated through mechanism (C) which involves the interaction of glucocorticoids with its receptor (GR) by non-genomic and (or) genomic pathways. In both cases the complex might directly target downstream effector proteins such as STAT, but, similar to pathway $\mathrm{B}$, the importance of this mechanism for cholesterol efflux in the mammary gland has not been studied yet. Finally, other factors might also be involved in the stimulation of STAT (mechanism D). Whether crosstalk exists between prolactin and ABCA1 signaling requires additional investigations

gland could be enhanced by using SCAP null mice [138, 139] to investigate the importance of SREBP2 in cholesterol biosynthesis and transport as well as its hormonal regulation, or by investigating LXR $\alpha$ knockout mice [140] to test the role of LXR $\alpha$ in mammary gland cholesterol homeostasis and milk composition.

Ultimately the acquired in vitro and in vivo knowledge may also lead to a better understanding of the patho-physiological and nutritional aspects of cholesterol. This could contribute to design strategies for the optimization of milk cholesterol content, which should match both elevated requirements of infants during the early postnatal life and the necessity to prevent cardiovascular diseases due to high dietary cholesterol intake in milk consumers of older age.

Acknowledgments The present paper was supported by the Swiss National Science Foundation through the National Centre of Competence in Research TransCure. The authors thank Xiao Huang for her major contribution in the design of the figures. 


\section{References}

1. Long CA, Patton S, McCarthy RD. Origins of the cholesterol in milk. Lipids. 1980;15(10):853-7.

2. McManaman J, Reyland M, Thrower E. Secretion and fluid transport mechanisms in the mammary gland: comparisons with the exocrine pancreas and the salivary gland. J Mammary Gland Biol Neoplasia. 2006;11(3-4):249-68.

3. McManaman J, Neville M. Mammary physiology and milk secretion. Adv Drug Deliv Rev. 2003;55(5):629-41.

4. Mani O, Korner M, Sorensen MT, Sejrsen K, Wotzkow C, Ontsouka CE, et al. Expression, localization, and functional model of cholesterol transporters in lactating and nonlactating mammary tissues of murine, bovine, and human origin. Am J Physiol Regul Integr Comp Physiol. 2010;299(2):R642-54.

5. Simons K, Toomre D. Lipid rafts and signal transduction. Nat Rev Mol Cell Biol. 2000;1(1):31-9.

6. Simons K, Ikonen E. Functional rafts in cell membranes. Nature. 1997;387(6633):569-72.

7. Gofflot F, Hars C, Illien F, Chevy F, Wolf C, Picard JJ, et al. Molecular mechanisms underlying limb anomalies associated with cholesterol deficiency during gestation: implications of Hedgehog signaling. Hum Mol Genet. 2003;12(10):1187-98.

8. Mishkel MA. Neonatal plasma lipids as measured in cord blood. Can Med Assoc J. 1974;111(8):775-80.

9. Isomura $\mathrm{H}$, Takimoto H, Miura F, Kitazawa S, Takeuchi T, Itabashi K, et al. Type of milk feeding affects hematological parameters and serum lipid profile in Japanese infants. Pediatr Int. 2011;53(6):807-13.

10. Albrecht $\mathrm{C}$, Huang $\mathrm{X}$, Ontsouka EC. Cholesterol transporters in lactating and non-lactating human mammary tissue. In: In dietary and nutritional aspects of human breast milk. Wageningen Academic Publishers; 2013.

11. Owen CG, Martin RM, Whincup PH, Davey-Smith G, Gillman MW, Cook DG. The effect of breastfeeding on mean body mass index throughout life: a quantitative review of published and unpublished observational evidence. Am J Clin Nutr. 2005;82(6): 1298-307.

12. Owen CG, Martin RM, Whincup PH, Smith GD, Cook DG. Effect of infant feeding on the risk of obesity across the life course: a quantitative review of published evidence. Pediatrics. 2005;115(5): 1367-77.

13. Rudnicka AR, Owen CG, Strachan DP. The effect of breastfeeding on cardiorespiratory risk factors in adult life. Pediatrics. 2007;119(5):e1107-15.

14. Peaker M. The mammary gland in mammalian evolution: a brief commentary on some of the concepts. J Mammary Gland Biol. 2002;7(3):347-53.

15. Victora CG, Vaughan JP, Lombardi C, Fuchs SMC, Gigante LP, Smith $\mathrm{PG}$, et al. Evidence for protection by breast-feeding against infant deaths from infectious-diseases in Brazil. Lancet. 1987;2(8554):319-22.

16. Picaud JC, Chapalain V, Paineau D, Zourabichvili O, Bornet FR, Duhamel JF. Incidence of infectious diseases in infants fed followon formula containing synbiotics: an observational study. Acta Paediatr. 2010;99(11):1695-700.

17. Haave NC, Innis SM. Cholesterol synthesis and accretion within various tissues of the fetal and neonatal rat. Metabolism. 2001;50(1):12-8.

18. Jensen RG. The composition of bovine milk lipids: January 1995 to December 2000. J Dairy Sci. 2002;85(2):295-350.

19. Oram JF, Vaughan AM. ATP-Binding cassette cholesterol transporters and cardiovascular disease. Circ Res. 2006;99(10):1031-43.

20. Llaverias G, Danilo C, Mercier I, Daumer K, Capozza F, Williams $\mathrm{TM}$, et al. Role of cholesterol in the development and progression of breast cancer. Am J Pathol. 2011;178(1):402-12.
21. Coughlin SS, Ekwueme DU. Breast cancer as a global health concern. Cancer Epidemiol. 2009;33(5):315-8.

22. Awad AB, Williams H, Fink CS. Phytosterols reduce in vitro metastatic ability of MDA-MB-231 human breast cancer cells. Nutr Cancer. 2001;40(2):157-64.

23. Dessi S, Batetta B, Pulisci D, Spano O, Anchisi C, Tessitore L, et al. Cholesterol content in tumor-tissues is inversely associated with high-density-lipoprotein cholesterol in serum in patients with gastrointestinal cancer. Cancer. 1994;73(2):253-8.

24. Freeman MR, Solomon KR. Cholesterol and prostate cancer. J Cell Biochem. 2004;91(1):54-69.

25. Li YC, Park MJ, Ye SK, Kim CW, Kim YN. Elevated levels of cholesterol-rich lipid rafts in cancer cells are correlated with apoptosis sensitivity induced by cholesterol-depleting agents. Am J Pathol. 2006;168(4):1107-18. quiz 1404-1105.

26. Martin BJ, van Golen KL. A comparison of cholesterol uptake and storage in inflammatory and noninflammatory breast cancer cells. Int J Breast Cancer. 2012;2012:412581.

27. Armstrong B, Doll R. Environmental factors and cancer incidence and mortality in different countries, with special reference to dietary practices. Int J Cancer. 1975;15(4):617-31.

28. Carroll KK, Gammal EB, Plunkett ER. Dietary fat and mammary cancer. Can Med Assoc J. 1968;98(12):590-4.

29. Kolonel LN, Hankin JH, Lee J, Chu SY, Nomura AMY, Hinds MW. Nutrient intakes in relation to cancer incidence in Hawaii. Brit $\mathrm{J}$ Cancer. 1981;44(3):332-9.

30. Yu SZ, Lu RF, Xu DD, Howe GR. A case-control study of dietary and nondietary risk factors for breast cancer in Shanghai. Cancer Res. 1990;50(16):5017-21.

31. Potischman N, Mcculloch CE, Byers T, Houghton L, Nemoto T, Graham S, et al. Associations between breast-cancer, plasma triglycerides, and cholesterol. Nutr Cancer. 1991;15(3-4):205-15.

32. Howe GR, Hirohata T, Hislop TG, Iscovich JM, Yuan JM, Katsouyanni K, et al. Dietary factors and risk of breast cancer: combined analysis of 12 case-control studies. J Natl Cancer Inst. 1990;82(7):561-9.

33. Bani IA, Williams CM, Boulter PS, Dickerson JW. Plasma lipids and prolactin in patients with breast cancer. Br J Cancer. 1986;54(3): 439-46.

34. Linzell JL, Peaker M. Mechanism of milk secretion. Physiol Rev. 1971;51(3):564-97.

35. Connor WE, Lin DS. Origin of milk cholesterol in the rabbit and guinea pig. Am J Physiol. 1967;213(6):1353-8.

36. Scow RO, Chernick SS, Fleck TR. Lipoprotein lipase and uptake of triacylglycerol, cholesterol and phosphatidylcholine from chylomicrons by mammary and adipose tissue of lactating rats in vivo. Biochim Biophys Acta. 1977;487(2):297-306.

37. Miller PS, Reis BL, Calvert CC, DePeters EJ, Baldwin RL. Patterns of nutrient uptake by the mammary glands of lactating dairy cows. J Dairy Sci. 1991;74(11):3791-9.

38. Zinder O, Mendelson CR, Blanchette-Mackie EF, Scow RO. Lipoprotein lipase and uptake of chylomicron triacylglycerol and cholesterol by perfused rat mammary tissue. Biochim Biophys Acta. 1976;431(3):526-37.

39. Wang YY, Tong J, Li SP, Zhang R, Chen L, Wang YH, et al. Overexpression of human lipoprotein lipase in mouse mammary glands leads to reduction of milk triglyceride and delayed growth of suckling pups. PLoS One. 2011;6(6):e20895.

40. Braun JE, Severson DL. Regulation of the synthesis, processing and translocation of lipoprotein lipase. Biochem J. 1992;287(Pt 2):337-47.

41. Lillis AP, Van Duyn LB, Murphy-Ullrich JE, Strickland DK. LDL receptor-related protein 1: unique tissue-specific functions revealed by selective gene knockout studies. Physiol Rev. 2008;88(3):887918.

42. Monks J, Huey PU, Hanson L, Eckel RH, Neville MC, Gavigan S. A lipoprotein-containing particle is transferred from the serum 
across the mammary epithelium into the milk of lactating mice. $\mathrm{J}$ Lipid Res. 2001;42(5):686-96.

43. Landschulz KT, Pathak RK, Rigotti A, Krieger M, Hobbs HH. Regulation of scavenger receptor, class B, type I, a high density lipoprotein receptor, in liver and steroidogenic tissues of the rat. J Clin Invest. 1996;98(4):984-95.

44. Ontsouka EC, Huang X, Stieger B, Albrecht C. Characteristics and functional relevance of apolipoprotein-A1 and cholesterol binding in mammary gland tissues and epithelial cells. PLoS One. 2013;8(7):e70407.

45. Miller WL. Steroid hormone synthesis in mitochondria. Mol Cell Endocrinol. 2013;379:62-73.

46. Chang TY, Chang CCY, Lin S, Yu CJ, Li BL, Miyazaki A. Roles of acyl-coenzyme A : cholesterol acyltransferase-1 and-2. Curr Opin Lipidol. 2001;12(3):289-96.

47. Ross AC, Rowe JF. Cholesterol esterification by mammary-gland microsomes from the lactating rat. Proc Soc Exp Biol Med. 1984;176(1):42-7.

48. Shand JH, West DW. Acyl-Coa-Cholesterol acyltransferase activity in the rat mammary-gland - variation during pregnancy and lactation. Lipids. 1991;26(2):150-4.

49. Suguro T, Watanabe T, Kanome T, Kodate S, Hirano T, Miyazaki A, et al. Serotonin acts as an up-regulator of acyl-coenzyme A : cholesterol acyltransferase-1 in human monocyte-macrophages. Atherosclerosis. 2006;186(2):275-81.

50. Martin-Hidalgo A, Huerta L, Alvarez N, Alegria G, Del Val TM, Herrera E. Expression, activity, and localization of hormonesensitive lipase in rat mammary gland during pregnancy and lactation. J Lipid Res. 2005;46(4):658-68

51. Zidi A, Fernandez-Cabanas VM, Carrizosa J, Jordana J, Urrutia B, Polvillo $\mathrm{O}$, et al. Genetic variation at the goat hormone-sensitive lipase (LIPE) gene and its association with milk yield and composition. J Dairy Res. 2010;77(2):190-8.

52. Yonezawa T, Haga S, Kobayashi Y, Katoh K, Obara Y. Regulation of hormone-sensitive lipase expression by saturated fatty acids and hormones in bovine mammary epithelial cells. Biochem Biophys Res Commun. 2008;376(1):36-9.

53. Botham KM, Martinez MJ, Ochoa B. Cholesteryl ester synthesis and hydrolysis in the rat mammary gland during pregnancy and lactation. J Biochem. 1993;114(3):415-20.

54. Maxfield FR, Wustner D. Intracellular cholesterol transport. J Clin Invest. 2002;110(7):891-8.

55. Pentchev PG. Niemann-Pick $C$ research from mouse to gene. Biochim Biophys Acta. 2004;1685(1-3):3-7.

56. Vanier MT, Millat G. Niemann-Pick disease type C. Clin Genet. 2003;64(4):269-81.

57. Mani O, Sorensen MT, Sejrsen K, Bruckmaier RM, Albrecht C. Differential expression and localization of lipid transporters in the bovine mammary gland during the pregnancy-lactation cycle. $\mathbf{J}$ Dairy Sci. 2009;92(8):3744-56.

58. Lev S. Nonvesicular lipid transfer from the endoplasmic reticulum. Cold Spring Harb Perspect Biol. 2012;4(10):pii: a013300.

59. Ikonen E. Cellular cholesterol trafficking and compartmentalization. Nat Rev Mol Cell Biol. 2008;9(2):125-38.

60. Hao MM, Lin SX, Karylowski OJ, Wustner D, McGraw TE, Maxfield FR. Vesicular and non-vesicular sterol transport in living cells - The endocytic recycling compartment is a major sterol storage organelle. J Biol Chem. 2002;277(1):609-17.

61. Raychaudhuri S, Im YJ, Hurley JH, Prinz WA. Nonvesicular sterol movement from plasma membrane to ER requires oxysterolbinding protein-related proteins and phosphoinositides. J Cell Biol. 2006;173(1):107-19.

62. Hynynen R, Laitinen S, Kakela R, Tanhuanpaa K, Lusa S, Ehnholm $\mathrm{C}$, et al. Overexpression of OSBP-related protein 2 (ORP2) induces changes in cellular cholesterol metabolism and enhances endocytosis. Biochem J. 2005;390:273-83.
63. Misumi Y, Miki K, Takatsuki A, Tamura G, Ikehara Y. Novel blockade by brefeldin A of intracellular transport of secretory proteins in cultured rat hepatocytes. J Biol Chem. 1986;261(24): 11398-403.

64. Lippincott-Schwartz J, Yuan LC, Bonifacino JS, Klausner RD. Rapid redistribution of Golgi proteins into the ER in cells treated with brefeldin A: evidence for membrane cycling from Golgi to ER. Cell. 1989;56(5):801-13.

65. Mather IH, Keenan TW. Origin and secretion of milk lipids. J Mammary Gland Biol Neoplasia. 1998;3(3):259-73.

66. Keenan TW. Assembly and secretion of the lipid globules of milk. Adv Exp Med Biol. 2001;501:125-36.

67. Mani O, Korner M, Ontsouka CE, Sorensen MT, Sejrsen K, Bruckmaier RM, et al. Identification of ABCA1 and ABCG1 in milk fat globules and mammary cells-implications for milk cholesterol secretion. J Dairy Sci. 2011;94(3):1265-76.

68. Mesilati-Stahy R, Mida K, Argov-Argaman N. Size-dependent lipid content of bovine milk fat globule and membrane phospholipids. J Agric Food Chem. 2011;59(13):7427-35.

69. Keenan TW. Milk lipid globules and their surrounding membrane: a brief history and perspectives for future research. J Mammary Gland Biol Neoplasia. 2001;6(3):365-71.

70. Patton S, Jensen RG. Lipid metabolism and membrane functions of the mammary gland. Prog Chem Fats Other Lipids. 1975;14(4): 163-277.

71. Nagao K, Takahashi K, Azuma Y, Takada M, Kimura Y, Matsuo M, et al. ATP hydrolysis-dependent conformational changes in the extracellular domain of ABCA1 are associated with apoA-I binding. J Lipid Res. 2012;53(1):126-36.

72. Rust S, Rosier M, Funke H, Real J, Amoura Z, Piette JC, et al. Tangier disease is caused by mutations in the gene encoding ATPbinding cassette transporter 1. Nat Genet. 1999;22(4):352-5.

73. Shulenin S, Nogee LM, Annilo T, Wert SE, Whitsett JA, Dean M. ABCA3 gene mutations in newborns with fatal surfactant deficiency. N Engl J Med. 2004;350(13):1296-303.

74. Ueda $\mathrm{K}$. ABC proteins protect the human body and maintain optimal health. Biosci Biotechnol Biochem. 2011;75(3):401-9.

75. Linsel-Nitschke P, Jehle AW, Shan J, Cao G, Bacic D, Lan D, et al. Potential role of ABCA7 in cellular lipid efflux to apoA-I. J Lipid Res. 2005;46(1):86-92.

76. Wang N, Lan D, Gerbod-Giannone M, Linsel-Nitschke P, Jehle AW, Chen W, et al. ATP-binding cassette transporter A7 (ABCA7) binds apolipoprotein A-I and mediates cellular phospholipid but not cholesterol efflux. J Biol Chem. 2003;278(44):42906-12.

77. Abe-Dohmae S, Ueda K, Yokoyama S. ABCA7, a molecule with unknown function. FEBS Lett. 2006;580(4):1178-82.

78. Kim WS, Fitzgerald ML, Kang K, Okuhira K, Bell SA, Manning JJ, et al. Abca7 null mice retain normal macrophage phosphatidylcholine and cholesterol efflux activity despite alterations in adipose mass and serum cholesterol levels. J Biol Chem. 2005;280(5):3989-95.

79. Reinhardt TA, Lippolis JD. Bovine milk fat globule membrane proteome. J Dairy Res. 2006;73(4):406-16.

80. Stefulj J, Panzenboeck U, Becker T, Hirschmugl B, Schweinzer C, Lang I, et al. Human endothelial cells of the placental barrier efficiently deliver cholesterol to the fetal circulation via $\mathrm{ABCA1}$ and ABCG1. Circ Res. 2009;104(5):600-8.

81. Lee J, Shirk A, Oram JF, Lee SP, Kuver R. Polarized cholesterol and phospholipid efflux in cultured gall-bladder epithelial cells: evidence for an ABCA1-mediated pathway. Biochem J. 2002;364(Pt 2):475-84

82. Liao Y, Alvarado R, Phinney B, Lonnerdal B. Proteomic characterization of human milk fat globule membrane proteins during a 12 month lactation period. J Proteome Res. 2011;10(8):3530-41.

83. Reinhardt TA, Lippolis JD. Developmental changes in the milk fat globule membrane proteome during the transition from colostrum to milk. J Dairy Sci. 2008;91(6):2307-18. 
84. Vorbach C, Scriven A, Capecchi MR. The housekeeping gene xanthine oxidoreductase is necessary for milk fat droplet enveloping and secretion: gene sharing in the lactating mammary gland. Genes Dev. 2002;16(24):3223-35.

85. McManaman JL, Palmer CA, Wright RM, Neville MC. Functional regulation of xanthine oxidoreductase expression and localization in the mouse mammary gland: evidence of a role in lipid secretion. J Physiol. 2002;545(Pt 2):567-79.

86. Heid HW, Schnolzer M, Keenan TW. Adipocyte differentiationrelated protein is secreted into milk as a constituent of milk lipid globule membrane. Biochem J. 1996;320(Pt 3):1025-30.

87. Langmann T, Klucken J, Reil M, Liebisch G, Luciani MF, Chimini $\mathrm{G}$, et al. Molecular cloning of the human ATP-binding cassette transporter 1 (hABC1): evidence for sterol-dependent regulation in macrophages. Biochem Biophys Res Commun. 1999;257(1):2933.

88. Farke C, Viturro E, Meyer HH, Albrecht C. Identification of the bovine cholesterol efflux regulatory protein $\mathrm{ABCA} 1$ and its expression in various tissues. J Anim Sci. 2006;84(11):2887-94.

89. Morroni M, Giordano A, Zingaretti MC, Boiani R, De Matteis R, $\mathrm{Kahn} \mathrm{BB}$, et al. Reversible transdifferentiation of secretory epithelial cells into adipocytes in the mammary gland. Proc Natl Acad Sci U S A. 2004;101(48):16801-6.

90. Umemoto T, Han CY, Mitra P, Averill MM, Tang CR, Goodspeed L, et al. Apolipoprotein AI and high-density lipoprotein have antiinflammatory effects on adipocytes via cholesterol transporters ATP-binding cassette A-1, ATP-binding cassette G-1, and scavenger receptor B-1. Circ Res. 2013;112(10):1345-54.

91. Schimanski S, Wild PJ, Treeck O, Horn F, Sigruener A, Rudolph C, et al. Expression of the lipid transporters $\mathrm{ABCA} 3$ and ABCA1 is diminished in human breast cancer tissue. Horm Metab Res. 2010;42(2):102-9.

92. Takahashi K, Kimura Y, Nagata K, Yamamoto A, Matsuo M, Ueda $\mathrm{K}$. ABC proteins: key molecules for lipid homeostasis. Med Mol Morphol. 2005;38(1):2-12.

93. Vaughan AM, Oram JF. ABCG1 redistributes cell cholesterol to domains removable by high density lipoprotein but not by lipiddepleted apolipoproteins. J Biol Chem. 2005;280(34):30150-7.

94. Kobayashi A, Takanezawa Y, Hirata T, Shimizu Y, Misasa K, Kioka $\mathrm{N}$, et al. Efflux of sphingomyelin, cholesterol, and phosphatidylcholine by ABCG1. J Lipid Res. 2006;47(8):1791-802.

95. Viturro E, Farke C, Meyer HH, Albrecht C. Identification, sequence analysis and mRNA tissue distribution of the bovine sterol transporters ABCG5 and ABCG8. J Dairy Sci. 2006;89(2):553-61.

96. Lee MH, Lu K, Hazard S, Yu H, Shulenin S, Hidaka H, et al. Identification of a gene, ABCG5, important in the regulation of dietary cholesterol absorption. Nat Genet. 2001;27(1):79-83.

97. Yu L, Hammer RE, Li-Hawkins J, Von Bergmann K, Lutjohann D, Cohen JC, et al. Disruption of Abcg5 and Abcg8 in mice reveals their crucial role in biliary cholesterol secretion. Proc Natl Acad Sci U S A. 2002;99(25):16237-42.

98. Yu L, Li-Hawkins J, Hammer RE, Berge KE, Horton JD, Cohen JC, et al. Overexpression of ABCG5 and ABCG8 promotes biliary cholesterol secretion and reduces fractional absorption of dietary cholesterol. J Clin Invest. 2002;110(5):671-80.

99. Berge KE, Tian H, Graf GA, Yu L, Grishin NV, Schultz J, et al. Accumulation of dietary cholesterol in sitosterolemia caused by mutations in adjacent ABC transporters. Science. 2000;290(5497): 1771-5.

100. Phillips MC, Gillotte KL, Haynes MP, Johnson WJ, Lund-Katz S, Rothblat GH. Mechanisms of high density lipoprotein-mediated efflux of cholesterol from cell plasma membranes. Atherosclerosis. 1998;137(Suppl):S13-7.

101. McLean LR, Phillips MC. Mechanism of cholesterol and phosphatidylcholine exchange or transfer between unilamellar vesicles. Biochemistry-us. 1981;20(10):2893-900.
102. Mukherjee S, Zha XH, Tabas I, Maxfield FR. Cholesterol distribution in living cells: fluorescence imaging using dehydroergosterol as a fluorescent cholesterol analog. Biophys J. 1998;75(4):1915-25.

103. Sankaranarayanan S, Kellner-Weibel G, de la Llera-Moya M, Phillips MC, Asztalos BF, Bittman R, et al. A sensitive assay for ABCA1-mediated cholesterol efflux using BODIPY-cholesterol. J Lipid Res. 2011;52(12):2332-40.

104. Schroeder F, Holland JF, Bieber LL. Fluorometric evidence for the binding of cholesterol to the filipin complex. J Antibiot (Tokyo). 1971;24(12):846-9.

105. Edwards SH, Kimberly MM, Pyatt SD, Stribling SL, Dobbin KD, Myers GL. Proposed serum cholesterol reference measurement procedure by gas chromatography-isotope dilution mass spectrometry. Clin Chem. 2011;57(4):614-22.

106. VanHouten J, Dann P, McGeoch G, Brown EM, Krapcho K, Neville $\mathrm{M}$, et al. The calcium-sensing receptor regulates mammary gland parathyroid hormone-related protein production and calcium transport. J Clin Invest. 2004;113(4):598-608.

107. Stockinger W, Castoreno AB, Wang Y, Pagnon JC, Nohturfft A. Real-time analysis of endosomal lipid transport by live cell scintillation proximity assay. J Lipid Res. 2004;45(11):2151-8.

108. Sorg D, Potzel A, Beck M, Meyer HH, Viturro E, Kliem H. Effects of cell culture techniques on gene expression and cholesterol efflux in primary bovine mammary epithelial cells derived from milk and tissue. In Vitro Cell Dev Biol Anim. 2012;48(9):550-3.

109. Jensen RG. The lipids in human milk. Prog Lipid Res. 1996;35(1): 53-92.

110. Neville MC, Picciano MF. Regulation of milk lipid secretion and composition. Annu Rev Nutr. 1997;17:159-83.

111. Oppi-Williams C, Suagee JK, Corl BA. Regulation of lipid synthesis by liver $\mathrm{X}$ receptor alpha and sterol regulatory element-binding protein 1 in mammary epithelial cells. J Dairy Sci. 2013;96(1):112-21.

112. Shand JH, West DW. Co-ordinate diurnal variations in the activities of cholesterol-metabolizing enzymes in the rat mammary gland. Biochem Soc Trans. 1989;17(6):1081-2.

113. Duncan RE, El-Sohemy A, Archer MC. Delivery of mevalonate to murine extrahepatic tissues via mini-osmotic pumps. J Pharmacol Toxicol Methods. 2004;50(2):139-43.

114. Bionaz M, Chen SW, Khan MJ, Loor JJ. Functional role of PPARs in ruminants: potential targets for fine-tuning metabolism during growth and lactation. Ppar Res. 2013;2013:28.

115. Desvergne B, Michalik L, Wahli W. Transcriptional regulation of metabolism. Physiol Rev. 2006;86(2):465-514.

116. Bjorkhem I, Diczfalusy U. Oxysterols: friends, foes, or just fellow passengers? Arterioscler Thromb Vasc Biol. 2002;22(5):734-42.

117. Schroepfer Jr GJ. Oxysterols: modulators of cholesterol metabolism and other processes. Physiol Rev. 2000;80(1):361-554.

118. Janowski BA, Grogan MJ, Jones SA, Wisely GB, Kliewer SA, Corey EJ, et al. Structural requirements of ligands for the oxysterol liver X receptors LXRalpha and LXRbeta. Proc Natl Acad Sci U S A. 1999;96(1):266-71.

119. McFadden JW, Corl BA. Activation of liver X receptor (LXR) enhances de novo fatty acid synthesis in bovine mammary epithelial cells. J Dairy Sci. 2010;93(10):4651-8.

120. Repa JJ, Mangelsdorf DJ. Nuclear receptor regulation of cholesterol and bile acid metabolism. Curr Opin Biotechnol. 1999;10(6):55763.

121. Bionaz M, Hausman GJ, Loor JJ, Mandard S. Physiological and nutritional roles of PPAR across species. PPAR Res. 2013;2013: 807156.

122. Shi HB, Luo J, Zhu JJ, Li J, Sun YT, Lin XZ, et al. PPAR gamma regulates genes involved in triacylglycerol synthesis and secretion in mammary gland epithelial cells of dairy goats. Ppar Res. 2013;2013:310948.

123. Bionaz M, Thering BJ, Loor JJ. Fine metabolic regulation in ruminants via nutrient-gene interactions: saturated long-chain fatty acids 
increase expression of genes involved in lipid metabolism and immune response partly through PPAR-alpha activation. Br J Nutr. 2012;107(2):179-91.

124. Schmitz G, Langmann T. Transcriptional regulatory networks in lipid metabolism control ABCA1 expression. Biochim Biophys Acta. 2005;1735(1):1-19.

125. Zinder O, Hamosh M, Fleck TRC, Scow RO. Effect of prolactin on lipoprotein-lipase in mammary-gland and adipose-tissue of rats. Am J Physiol. 1974;226(3):744-8.

126. Da Costa TH, Williamson DH. Regulation of rat mammary-gland uptake of orally administered [1-14C] triolein by insulin and prolactin: evidence for bihormonal control of lipoprotein lipase activity. Biochem J. 1994;300(Pt 1):257-62.

127. Barber MC, Clegg RA, Finley E, Vernon RG, Flint DJ. The role of growth hormone, prolactin and insulin-like growth factors in the regulation of rat mammary gland and adipose tissue metabolism during lactation. J Endocrinol. 1992;135(2):195-202.

128. Fliss MS, Hinkle PM, Bancroft C. Expression cloning and characterization of PREB (prolactin regulatory element binding), a novel WD motif DNA-binding protein with a capacity to regulate prolactin promoter activity. Mol Endocrinol. 1999;13(4):644-57.

129. Neville MC, Anderson SM, McManaman JL, Badger TM, Bunik $\mathrm{M}$, Contractor N, et al. Lactation and neonatal nutrition: defining and refining the critical questions. J Mammary Gland Biol Neoplasia. 2012;17(2):167-88.

130. Ross R. The pathogenesis of atherosclerosis: a perspective for the 1990s. Nature. 1993;362(6423):801-9.

131. Witztum JL, Steinberg D. Role of oxidized low-density-lipoprotein in atherogenesis. J Clin Invest. 1991;88(6):1785-92.

132. Sakai M, Kobori S, Miyazaki A, Horiuchi S. Macrophage proliferation in atherosclerosis. Curr Opin Lipidol. 2000;11(5): 503-9.

133. Annema W, Tietge UJ. Regulation of reverse cholesterol transport a comprehensive appraisal of available animal studies. Nutr Metab (Lond). 2012;9(1):25.

134. Calpe-Berdiel L, Rotllan N, Palomer X, Ribas V, Blanco-Vaca F, Escola-Gil JC. Direct evidence in vivo of impaired macrophagespecific reverse cholesterol transport in ATP-binding cassette transporter A1-deficient mice. Biochim Biophys Acta. 2005;1738(1-3): 6-9.
135. Calpe-Berdiel L, Rotllan N, Fievet C, Roig R, Blanco-Vaca F, Escola-Gil JC. Liver X receptor-mediated activation of reverse cholesterol transport from macrophages to feces in vivo requires ABCG5/G8. J Lipid Res. 2008;49(9):1904-11.

136. Zhang Y, Da Silva JR, Reilly M, Billheimer JT, Rothblat GH, Rader DJ. Hepatic expression of scavenger receptor class B type I (SR-BI) is a positive regulator of macrophage reverse cholesterol transport in vivo. J Clin Invest. 2005;115(10):2870-4.

137. Moore RE, Navab M, Millar JS, Zimetti F, Hama S, Rothblat GH, et al. Increased atherosclerosis in mice lacking apolipoprotein A-I attributable to both impaired reverse cholesterol transport and increased inflammation. Circ Res. 2005;97(8):763-71.

138. Rudolph MC, Monks J, Burns V, Phistry M, Marians R, Foote MR, et al. Sterol regulatory element binding protein and dietary lipid regulation of fatty acid synthesis in the mammary epithelium. Am J Physiol Endocrinol Metab. 2010;299(6):E918-27.

139. Rudolph MC, Russell TD, Webb P, Neville MC, Anderson SM. Prolactin-mediated regulation of lipid biosynthesis genes in vivo in the lactating mammary epithelial cell. Am J Physiol Endocrinol Metab. 2011;300(6):E1059-68.

140. Peet DJ, Turley SD, Ma W, Janowski BA, Lobaccaro JM, Hammer RE, et al. Cholesterol and bile acid metabolism are impaired in mice lacking the nuclear oxysterol receptor LXR alpha. Cell. 1998;93(5): 693-704.

141. Smith JL, Lear SR, Forte TM, Ko W, Massimi M, Erickson SK. Effect of pregnancy and lactation on lipoprotein and cholesterol metabolism in the rat. J Lipid Res. 1998;39(11):2237-49.

142. Tang C, Liu Y, Kessler PS, Vaughan AM, Oram JF. The macrophage cholesterol exporter ABCA1 functions as an anti-inflammatory receptor. J Biol Chem. 2009;284(47):32336-43.

143. Picciano MF. Representative values for constituents of human milk. Pediatr Clin N Am. 2001;48(1):263-4.

144. Bitman J, Freed LM, Neville MC, Wood DL, Hamosh P, Hamosh M. Lipid composition of prepartum human mammary secretion and postpartum milk. J Pediatr Gastroenterol Nutr. 1986;5(4):608-15.

145. Jandal JM. Comparative aspects of goat and sheep milk. Small Rumin Res. 1996;22(2):177-85.

146. Park YW, Juarez M, Ramos M, Haenlein GFW. Physico-chemical characteristics of goat and sheep milk. Small Rumin Res. 2007;68(1-2):88-113. 